\title{
Effect of Salt Water on Mechanical Properties of Conventional and Pervious Concrete
}

\author{
Agrawal Achal ${ }^{1}$, Chandak, N. R. ${ }^{2}$ \\ ${ }^{1}$ Assistant Professor, Department of Civil Engineering, NMIMS, MPSTME, Shirpur, M.S. India, \\ ${ }^{2}$ Corresponding Author, Professor, Department of Civil Engineering, NMIMS, MPSTME, Shirpur, M.S. India,
}

\begin{abstract}
Pervious concrete is a special high porosity concrete used for roads carrying light traffic, allows the water from precipitation and thereby reducing the runoff from a road surface and hence recharging ground water levels. Objective of this research is to find mechanical properties i.e. compressive strength, split tensile strength and flexural strength of the pervious concrete. The main problem of pervious concrete pavement is the strength itself. The conventional and pervious concrete is tested for 28 days of curing period with fresh water \& salt water. For conventional concrete the mix proportion is considered as 1:1.5:3 and that of for pervious concrete 1:4. Water cement ratio of 0.3 for both conventional and pervious concrete is adopted. Fresh water $(F W)$ is a tap water and salt water (SW) is prepared by adding of common salt (2.5\%), detergent (2.5\%) by volume. From experimental results, it is observed that use of salt water for curing of concrete, improved the mechanical properties of both the conventional and pervious concrete for the period of 28 days.
\end{abstract}

Keywords: Pervious concrete, Salt water, Compressive strength, Split tensile strength, Flexural strength.

\section{Introduction}

Pervious concrete which is also known as the no-fines, porous, gap-graded, and permeable concrete. It has been found to be a reliable storm water management tool. By definition, pervious concrete is a mixture of gravel or granite stone, cement, water, little to no sand (fine aggregate) with or without admixtures. When pervious concrete is used for paving, the open cell structures allow storm water to filter through the pavement and into the underlying soils. Pervious concrete can be used in a wide range of applications, although its primary use is in pavements which are in: residential roads, alleys and driveways, low volume pavements, low water crossings, sidewalks and pathways, parking areas, tennis courts, slope stabilization, sub-base for conventional concrete pavements etc. [1] The performance of slag concrete exposed to artificially made sea water. They concluded that the development of compressive strength for slag concrete is not significant at the early age of curing. The gain in strength occurs at relatively rapid ate at later ages of curing. Mix proportion of slag with cement has a significant effect on strength development of slag concrete. Among the mix proportions studied, the 70:30 mix slag concrete shows higher compressive strength. [2] studied the effect of different concentrations of ammonia in the popular image on the physical, chemical and mechanical properties of different types of cement such as SRC; OPC and HSC. The electrochemical measurement (linear polarization systems) as well as infrared spectroscopy (IR) were used in this study. The behavior of reinforced steel embedded in SRC; OPC and HSC with (5 wt. \%) ammonium sulphate solution were determined. The results showed that ammonia gets a harmful effect on OPC and SRC mortars but HSC shows high resistivity. Also, the reinforced steel is greatly affected in the aggressive medium containing ammonium solution. The effects of percentage of fine aggregates and cement to coarse aggregate ratio on the important engineering properties of pervious concrete were investigated [3]. As per the test results, maximum compressive strength of pervious concrete was achieved by using the $20 \mathrm{~mm}$ graded aggregate and 1:4 cement: total aggregate ratio. [4] studied the properties of pervious concrete used for bridge superstructure. They concluded that use of this concrete is suitable bridge superstructure. [5] employed testing processes for pervious concrete that are more representative of field conditions to determine the effects of the inclusion of sand as a fine aggregate; fly ash, slag and silica fume as cementitious alternatives, and construction practices on freeze-thaw durability and deicing salts exposure of pervious concrete. The pervious concrete helps in attenuate storm water problems, reduce the absorption of solar radiation but requires regular maintenance to prevent any clogging of the pores by sediments and vegetation [6].

\section{Mix Design and Proportioning}

The porosity in pervious concrete is created by the reduction or elimination of fine aggregate from the concrete mix design. Standard pervious concrete in India is a mixture of a single-size coarse aggregate and cement combined at low water to cement ratios. Strength is often the primary concern for concrete pavement designs. Since pervious concrete has a high void ratio (15\%-35\%), often without fine aggregate the compressive, tensile, and flexural strengths tend to be lower than that of conventional concrete. 
The mix design of conventional concrete is done as per the steps given in IS 10262:2009 [7]. The mix proportion for conventional concrete is 1:1.5:3 (M20). Typical mix designs of pervious concrete had been recommended by different agencies such as National Ready Mixed Concrete Association (NRMCA), the Southern California Ready Mix Concrete Association (SCRMCA) and the Euclid Chemical Company (ECC) [2]. Based upon trial mixes the cement content of $375 \mathrm{~kg} / \mathrm{m} 3$ was finalize. The mix proportion for pervious concrete is considered in this study is $1: 4$ with $0 \%$ of fine aggregates. The size of course aggregate is taken as $50 \% 12.5 \mathrm{~mm}$ aggregates, $50 \% 10 \mathrm{~mm}$ aggregates so as to have sufficient voids. Water cement ratio of 0.3 was adopted for all the samples. The mixing of all ingredients is carried by tilting drum concrete mixer to ensure uniform mixing. The samples were cured for 28 days under tap water (FW) and salt water (SW) which is prepared by adding of common salt $(2.5 \%)$, detergent $(2.5 \%)$ by volume of tap water.

\section{Experimental Program and Results}

The experimental work is carried out to study the various parameters of pervious concrete and its comparison is done with conventional concrete.

\section{a. Compressive strength}

The blocks made of conventional concrete with 1:1.5:3 cement sand and aggregate ratio with 0.30 of water cement ratio were cured with fresh water (FW) for 28 days, the average compressive strength was $22.55 \mathrm{MPa}$ and when the same sample mix was cured with salt water (SW) for 28 days the average compressive strength was $23.51 \mathrm{MPa}$ which is a $4.2 \%$ higher. As shown in Table 1.

Cubes made of pervious concrete with 1:4 cement-aggregate ratio and 0.3 water cement ratio were cured with fresh water for 28 days, the average compressive strength was $9.44 \mathrm{MPa}$ and when the same sample mix was cured with salt water for 28 days the average compressive strength was $10.83 \mathrm{MPa}$ which is a $14.72 \%$ higher. Compressive strength of pervious concrete cured with FW and SW is shown in Table 2. It is observed that there is huge reduction in the compressive strength of pervious concrete i.e. $41.86 \%$ when compared to that of conventional concrete, when cured with FW. Also, the reduction in strength is $46 \%$, when cured with SW. This shows that fine aggregate plays a vital role in imparting the strength to the concrete. Also, salt water enhancing the strength, though the percentage increase is minimal.

Table 1. Compressive Strength of Conventional Concrete cured with FW and SW

\begin{tabular}{|c|c|c|c|}
\hline S. No. & Mix Proportion & 28 days Compressive Strength (FW) (MPa) & 28 days Compressive Strength (SW) (MPa) \\
\hline 1 & $1: 1.5: 3$ & 22.52 & 24.64 \\
\hline 2 & $1: 1.5: 3$ & 22.52 & 22.49 \\
\hline 3 & $1: 1.5: 3$ & 22.63 & 23.40 \\
\hline Average Compressive Strength $(\mathrm{MPa})$ & 22.55 & 23.51 \\
\hline
\end{tabular}

Table 2. Compressive Strength of Pervious Concrete cured with FW and SW

\begin{tabular}{|c|c|c|c|}
\hline S. No. & Mix Proportion & 28 days Compressive Strength (FW) (MPa) & 28 days Compressive Strength (SW) (MPa) \\
\hline 1 & $1: 4$ & 8.72 & 9.93 \\
\hline 2 & $1: 4$ & 9.60 & 10.86 \\
\hline 3 & $1: 4$ & 10.01 & 11.72 \\
\hline Average Compressive Strength $(\mathrm{MPa})$ & 9.44 & 10.83 \\
\hline
\end{tabular}

\section{b. Split Tensile Test}

Concrete is strong in compression and weak in tension. Tensile forces are taken mainly by reinforcement. Due to tension, cracks are formed. This test is based on the fact that circular disc is subjected to compression load diametrically. As per IS 5816-1970 [8] the split tensile strength of the concrete is given by:

$$
F=\frac{2 P}{\pi D L}
$$

Where, $\mathrm{P}$ is the maximum load, $\mathrm{D}$ is the diameter of the cylinder, $\mathrm{L}$ is the length of the cylinder. The test is conducted on $15 \mathrm{~cm}$ diameter and $30 \mathrm{~cm}$ height cylinder placed centrally between the cross heads of compression testing machine. For conventional concrete, the average tensile strength was $3.24 \mathrm{MPa}$ at 28 days of curing with fresh water and when the same mix, cured with salt water for 28 days the average tensile strength was $3.44 \mathrm{MPa}$ which is $5.82 \%$ higher. Table 3 shows the tensile strength of conventional concrete cured with FW and SW. For pervious concrete, the average tensile strength was $2.23 \mathrm{MPa}$ at 28 days of curing with fresh water and when the same sample mix was cured with salt water for 28 days the average tensile strength was 2.71 MPa which is $21.52 \%$ higher. Table 4 shows the tensile strength of pervious concrete cured with fresh water and water with salt. It is observed that there is huge reduction in the tensile strength of pervious concrete i.e. $31.18 \%$ when compared to that of conventional concrete when cured with FW. Also, the strength reduction is $21.22 \%$ when cured with SW. 
Table 3. Split Tensile Strength of Conventional Concrete cured with FW and SW

\begin{tabular}{|c|c|c|c|}
\hline S. No. & Mix Proportion & $\begin{array}{c}\text { Tensile Strength (FW) } \\
\text { (MPa) }\end{array}$ & Tensile Strength (SW) (MPa) \\
\hline 1 & $1: 1.5: 3$ & 2.90 & 3.34 \\
\hline 2 & $1: 1.5: 3$ & 3.49 & 3.49 \\
\hline 3 & $1: 1.5: 3$ & 3.34 & 3.49 \\
\hline \multicolumn{2}{|c|}{ Average Tensile strength (MPa) } & 3.24 & 3.44 \\
\hline
\end{tabular}

Table 4. Split Tensile Strength of Pervious Concrete cured with FW and SW

\begin{tabular}{|c|c|c|c|}
\hline S. No. & Mix Proportion & $\begin{array}{c}\text { Tensile Strength (FW) } \\
(\mathrm{MPa})\end{array}$ & $\begin{array}{c}\text { Tensile Strength (SW) } \\
\text { (MPa) }\end{array}$ \\
\hline 1 & $1: 4$ & 2.61 & 2.90 \\
\hline 2 & $1: 4$ & 2.32 & 2.61 \\
\hline 3 & $1: 4$ & 1.75 & 2.61 \\
\hline \multicolumn{2}{|c|}{ Average Tensile Strength (MPa) } & 2.23 & 2.71 \\
\hline
\end{tabular}

\section{c. Flexural Strength}

As per IS 456:2000 [9], the flexural strength of concrete is calculated as:

$$
\mathrm{f}_{\mathrm{cr}}=0.7 \sqrt{ } \mathrm{f}_{\mathrm{ck}}
$$

Where, $f_{c k}$ is is the characteristic cube compressive strength of concrete in $\mathrm{N} / \mathrm{mm}^{2}$. The flexural strength of conventional concrete when cured with FW and SW is shown in Table 5. For conventional concrete, the average flexural strength was $3.68 \mathrm{MPa}$ at 28 days of curing with fresh water and when the same sample mix, cured with salt water for 28 days the average flexural strength was $3.82 \mathrm{MPa}$, which is $3.80 \%$ higher.

For pervious concrete, the average flexural strength was $0.40 \mathrm{MPa}$ at 28 days of curing with fresh water and when the same mix was cured with salt water for 28 days the average flexural strength was $0.416 \mathrm{MPa}$ which is $3.85 \%$ higher. Table 6 shows the flexural strength of pervious concrete cured with FW and SW. It is observed that there is reduction in the flexural strength of pervious concrete i.e. $89.13 \%$ when compared to that of conventional concrete when cured with FW. Also, the strength reduction is $89.10 \%$ when cured with SW.

Table 5. Flexural Strength of Conventional Concrete cured with FW and SW

\begin{tabular}{|c|c|c|c|}
\hline \multirow{2}{*}{ S. No. } & Mix Proportion & $\begin{array}{c}\text { Flexural Strength (FW) } \\
\text { (MPa) }\end{array}$ & $\begin{array}{c}\text { Flexural Strength (SW) } \\
\text { (MPa) }\end{array}$ \\
\hline \multirow{2}{*}{1} & \multirow{3}{*}{$1.5: 3$} & 3.23 & 3.33 \\
\cline { 3 - 4 } & & 3.97 & 4.12 \\
\hline 2 & 3.85 & 4.02 \\
\hline 3 & 3.68 & 3.82 \\
\hline Average Flexural Strength (MPa) & \multicolumn{2}{|c}{} \\
\hline
\end{tabular}

Table 6. Flexural Strength of Pervious Concrete cured with FW and SW

\begin{tabular}{|c|c|c|c|}
\hline \multirow{2}{*}{ S. No. } & \multirow{2}{*}{ Mix Proportion } & $\begin{array}{c}\text { Flexural Strength (FW) } \\
\text { (MPa) }\end{array}$ & $\begin{array}{c}\text { Flexural Strength (SW) } \\
(\text { MPa) }\end{array}$ \\
\hline \multirow{2}{*}{1} & \multirow{3}{*}{$1: 4$} & 0.39 & 0.42 \\
\cline { 3 - 4 } & & 0.41 & 0.42 \\
\cline { 3 - 4 } & & 0.40 & 0.41 \\
\hline 3 & 0.40 & 0.416 \\
\hline \multicolumn{2}{|c|}{ Average Flexural Strength (MPa) } & & \\
\hline
\end{tabular}

\section{Conclusion}

From the experimental work and the results obtained it can be concluded that:

- The fine aggregate plays a vital role in imparting the strength to the concrete. Also, salt water enhancing the strength in the early stage.

- The compressive strength of conventional concrete and pervious concrete increased in all cases when curing is done with salt water, to that of the compressive strength of both the concrete cured with fresh water.

- The split tensile strength as well as flexural strength improves considerably when cured with salt-detergent solution.

- The study can be extended for longer period i.e. 60 days, 90 days and 365 days for better understanding of effect of salt detergent solution on the strength of conventional and pervious concrete as well.

\section{Acknowledgement}

Authors of the paper acknowledge the facility rendered by the management, SVKM's NMIMS (Deemed-to-be University) Shirpur, for conducting the experimental work and completing this research work in time. 


\section{References}

[1]. Md. Moinul Islam, Md. Saiful Islam, Bipul Chandra Mondal and Mohammad Rafiqul Islam, Strength behaviour of concrete using slag with cement in sea water environment, Journal of Civil Engineering (IEB), 38 (2), 2010, 129-140.

[2]. Magdy A. Abd El-Aziz, Waleed H. Sufe, Effect of sewage wastes on the physico-mechanical properties of cement and reinforced steel, Ain Shams Engineering Journal, 4, 2013, 387-391.

[3]. Sanket Sharma, Sarita Singla and Taranjeet Kaur, Mechanical properties of pervious concrete, Int. Conf. on Advances in Civil Engineering (ACCE), India, 2012, 161-164.

[4]. Lund, Mia Schou Møller; Hansen, Kurt Kielsgaard; Hertz, Kristian Dahl, Experimental study of properties of pervious concrete used for bridge superstructure", $12^{\text {th }}$ International Symposium on Concrete Roads, European Concrete Paving Association, Technical University Denmark (DTU), Denmark, 2014, 1-11.

[5]. Anderson, Walsh, Oka, Dewoolkar, Limberg, Sevi, Schmeckpeper, Laboratory performance of pervious concrete subjected to deicing salts and freeze-thaw, UVM Transportation Research Centre Report, 2015, 15-006.

[6]. Mohammed Sonebi, Mohamed Bassuoni, Ammar Yahia, Pervious concrete: mix design, properties and applications, RILEM Technical Letters, 1, 2016, 109 - 115.

[7]. IS 10262 (2009): Guidelines for concrete mix design proportioning, published by Bureau of Indian Standard, India.

[8]. IS 5816 (1999): Method of Test Splitting Tensile Strength of Concrete, published by Bureau of Indian Standard, India.

[9]. IS 456 (2000): Plain and reinforced concrete (fourth revision), published by Bureau of Indian Standard, India. 